\title{
Global Virtual Team Leadership Scale (GVTLS) Development in Multinational Companies
}

\author{
Sema Nur Batırlık ${ }^{1}$, Yasin Galip Gencer ${ }^{1}$ and Ulas Akkucuk ${ }^{2, *(1)}$ \\ 1 Department of International Trade and Finance, Yalova University, Yalova 77200, Turkey; \\ 197221004@ogrenci.yalova.edu.tr (S.N.B.); yggencer@yalova.edu.tr (Y.G.G.) \\ 2 Department of Management, Bogazici University, Istanbul 34342, Turkey \\ * Correspondence: ulas.akkucuk@boun.edu.tr
}

Citation: Batırlık, S.N.; Gencer, Y.G.; Akkucuk, U. Global Virtual Team Leadership Scale (GVTLS) Development in Multinational Companies. Sustainability 2022, 14 , 1038. https://doi.org/10.3390/ su14021038

Academic Editors: Ilsang Ko and Daniel Beimborn

Received: 15 December 2021

Accepted: 13 January 2022

Published: 17 January 2022

Publisher's Note: MDPI stays neutral with regard to jurisdictional claims in published maps and institutional affiliations.

Copyright: () 2022 by the authors. Licensee MDPI, Basel, Switzerland. This article is an open access article distributed under the terms and conditions of the Creative Commons Attribution (CC BY) license (https:// creativecommons.org/licenses/by/ $4.0 /)$.

\begin{abstract}
As a result of developments in technology, globalization and digitalization, virtual teams have become indispensable for many industries. Transformations in information and communication technology have provided new opportunities for businesses to create and manage virtual teams. Today, all organizations have had to introduce new methods of communication and have started to continue their conversations through digital platforms. It has become inevitable for teams to form in such virtual environments. Virtual team members are made up of individuals from different genders, experiences, cultures and geographic locations. While there are leaders in virtual teams as in face-to-face environments, this type of leadership performs its function through information and communication technologies, unlike traditional types. Although there are many studies on face-to-face leadership in academic studies and despite the increasing use of digital platforms, it is observed that there is a need for studies on leadership styles in virtual organizations. The main purpose of this study is to create a scale about leadership characteristics in virtual teams. With the present study, it is aimed to develop a valid and reliable scale in order to discover and analyze the virtual team leadership characteristics of individuals within the multinational companies. During the scale development process, literature review, focus group interviews and statistical analysis were used to create the items to be included in the scale. First of all, focus group discussions were conducted by examining the scale developments on the leadership phenomenon. A total of three focus group interviews were held; expert opinions were used to ensure the content validity of the results, and a draft scale with 29 items was created as a result.
\end{abstract}

Keywords: multinational company; virtual team; leadership; scale development; virtual team leadership

\section{Introduction}

With the rapid advances in technology, communication technology has developed and the level of communication has increased through virtual communication tools. In the current state of the world, individuals, regardless of status, access and use the data they want thanks to information and communication technologies. The increase in the rate of digitalization in the world has increased the communication levels of individuals in different regions. In the last couple of years of the 20th century, with the beginning of the personal computer era, businesses have also adapted to this technological progress resulting in positive aspects and developments such as opening a new business, saving time, not being bound by borders, and minimizing geographical distances.

Businesses have to cope with dynamic, constantly changing and complex environments, and this brings countless challenges. Commercial concerns in the new economic environment where the competitive conditions have changed cause a tendency to create different organizational designs that can meet the needs of the new age. Research shows that organizations need to bring the right people together at the right time to accomplish certain tasks. At this point, virtual teams have emerged in order to keep up with the needs of the new era. 
Virtual teams have been mentioned as early as the 1960s in the US [1]. Such teams allow organizations to work with individuals in different locations, saving on installation, maintenance and travel costs. With the widespread use of the Internet, virtual teams have made it possible to reduce the barriers between groups in different regions in many countries of the world. Different definitions may be given for virtual teams. One definition suggests that "virtual teams are distributed work teams whose members are geographically dispersed and coordinate their work predominantly with electronic information and communication technologies (e-mail, video-conferencing, telephone, etc.)" [2]. Virtual teams are more important nowadays as the global pandemic has forced many people to work from home even if the locations are very close. In addition, virtual teams allow team members from different countries to collaborate on projects. With the advent of virtual teams the concept of virtual team leadership has also developed. In order to increase the effectiveness of organizations in the new environment that has arisen as a result of globalization and technological developments, independent of time, place and geographical boundaries, virtual team leadership has emerged together with virtual teams [3].

The importance of virtual teams is far too great to be underestimated for effective and efficient communication among the members of multinational companies working in different regions. Virtual teams, which have many advantages such as personnel diversity, flexible organizational structure and innovation resource allocation, are widely used in many areas such as out-of-service resource use, R\&D and information technologies [4]. Virtual teams cross cultural, geographical and organizational boundaries, allowing businesses to be a part of strategic and global projects.

Due to the COVID-19 (coronavirus) pandemic that affected the world as of 2019, especially at the global level, it has been realized that there are very important changes and transformations in educational practices, economy and social life [5-7]. At this point, it can be seen that the importance and necessity of virtual teams has increased. Multinational companies are among the organizations that use virtual teams more actively in the current period than in the past. While there is a central control system for all departments in such companies, it is important that these departments follow policies related to each other and that there are organizations that control small company units in other countries [8]. Multinational corporations are organizations that have branches, companies and partners which are different from the central management. Branches and small company structures located in different places and those located in the headquarters act in harmony [9]. While the sale of the products and services that are produced starts and ends within the same organization, the distribution and marketing of the goods is done by the organizations affiliated to these companies [10]. Multinational companies, which are said to assume the leading role of the developing and changing world, have an important mission in economic activities. The reason why they are constantly expanding and increasing their power is that production, consumption and the dominant capital is bound to spread between countries [11]. With the increase in technological developments, multinational company structures have had the opportunity to dramatically increase in number. These types of companies, which reduce communication and distribution costs, have divided the production process into parts with technological development. Thus, the spread of this company type around the world has been realized by ensuring that every possible production/service-related process is realized in the different regions.

The aim of this research is to explain virtual teams and the concept of virtual team leadership, to learn the leadership perceptions of individuals who are employees of multinational companies in organizations held in virtual environments, and to develop a scale about virtual team leadership. It is noteworthy that virtual environments are ignored in studies dealing with the phenomenon of leadership in the literature. The subject of this research is the type of leadership that is mostly ignored in today's world where the level of Internet use is high, people use virtual platforms to communicate, and businesses hold meetings or trainings on these platforms. With this research, it is aimed to fill the gap in 
the academic literature by defining virtual team leadership and developing a scale on it which is to be called the "GVTL Scale-GVTLS".

In the next section of the study a multidimensional framework will be developed about virtual teams and leadership in virtual teams, following that the next section will present and describe focus group interviews and the pilot study, which are data collection tools for the study. At this stage, as a result of examining the leadership scales in the literature, focus group interviews, which are among the qualitative research methods, were used in order to create the expressions to be used for the focus groups study. Expert opinions were used to ensure the content validity of the resulting statements. Afterwards, the scale development process is explained along with the pilot study. The pilot application is carried out with the participation of multinational company employees located in the Marmara region of Turkey. Statistical analysis of the data obtained at the other stage was made using the SPSS package program, and their validity and reliability degrees were determined. Finally, the construct validity was listed by performing factor analysis and the study was terminated. We present the full GVTLS scale with 29 elements in the results section and present our discussion and conclusions as well.

\section{Virtual Team Leadership: A Multidimensional Framework}

Leadership exhibits a vital role in helping virtual teams overcome difficulties and achieve sound benefits. Within the popular leadership literature, academics dealing with virtual leaders have focused on two areas, namely leader behaviors and leader characteristics [12]. The classical two-dimensional framework dominated leadership research from the 1950s to the 1970s. In recent years, the first of the two-dimensional framework that has attracted the attention of academics is task-oriented leader behavior, while the other is relationship-oriented leader behavior.

Task-oriented leader behaviors focus on determining the roles and responsibilities of both the leader and team members, providing guidance to clarify and fulfill the objectives of the tasks, and monitoring business processes. Research shows that task-oriented behaviors, such as establishing shared norms and articulating team structures, are associated with virtual team success.

The relationship-oriented approach to leader behavior emphasizes the well-being of members and supporting members, and the importance of establishing good relations between the leader and the members. Leaders with relationship-oriented leader behavior attach importance to keeping good relations with employees, subordinates and team members [13]. Such a leader responds to the social needs of their employees by establishing a sincere and natural relationship. Treating the members of the organization with respect, paying attention to the members and valuing them form the basis of relationship-oriented leader behavior. While Fiedler notes that the effective behavior of the leadership can be realized according to the individual relations or the task, he also argues that the two leadership structures cannot be effective all the time [14].

In the task-oriented leadership type, the priority of the leader is the task of ensuring that the team members use the available resources effectively by performing the assigned task on time and in place. In the relationship-oriented type of leadership, the leader focuses on establishing mutual relations with team members, helping his subordinates in their duties, establishing team awareness and ensuring the personal development of employees [15].

The task-oriented type leader clarifies and defines the roles of team members, and establishes and supervises existing resources, organizational charts and communication ways $[16,17]$. The leader in the relationship-oriented type strives to keep the morale and desire of his employees high. Success in team building and sharing leadership with people who accept the relationship-oriented leadership type are at a higher level than other leadership types [17]. According to research, it has been determined that the task-oriented leadership type is widely and effectively used due to the centralized understanding of 
Turkish managers, not assigning duties to subordinates unless necessary, not looking at delegating authority, and the fact that the hierarchical order is clearly settled and accepted [15]

In virtual teams, roles and responsibilities are mostly carried out through virtual channels. This situation is different in geographically different working environments. It reveals the importance of virtual cooperation, which expresses collective behaviors performed by group members to facilitate effective communication with their friends. Virtual collaboration, which is one of the most important processes within virtual teams, contributes to team performance [18].

In order to effectively lead a virtual team and increase its effectiveness, it is imperative for leaders to manage conflict [19]. Team conflict can be defined as the perception of members about their individual differences, incompatibilities and irresoluble wishes and desires [20]. When there is team conflict, the type of conflict and the relationships differ depending on whether they are related to tasks or processes [21].

While awareness of team members' interpersonal otherness is considered as relationship conflict, task conflict refers to the perceptions of members about their different views about their role in the team. Process conflict, which is related to task conflict, arises according to the members' perception of differences in how they perform team tasks.

Studies show that relationship conflict almost always has a negative impact on the functioning of the team [22]. However, due to the different perspectives brought by the members, a certain level of task conflict can be beneficial for team effectiveness [23]. Relationship conflict is more likely to occur in virtual teams because individuals are more likely to attribute behaviors that violate malfunctioning group processes to personal factors rather than situational factors in a virtual environment [24]. Consequently, differences seen as task conflict in a face-to-face team can be understood as relational conflict, which ultimately hinders effective collaboration between members and emphasizes the significance of leader behaviors focused on building virtual team relationships. Effective communication can help prevent relationship conflicts. To encourage member communication in virtual teams, leaders may think about holding face-to-face meetings and "virtual parties", establishing communication routines and activating accessible virtual communication channels as needed.

Leader behaviors that clarify member responsibilities and guide task coordination help reduce task conflict and increase team effectiveness. In addition, leaders can hold virtual conferences to avoid potential misunderstandings due to lack of communication. Removing barriers to interpersonal relationships forms the basis of other team processes [25]. Therefore, to avoid task conflicts in virtual teams, leaders encourage using virtual communication tools to elucidate task responsibility, enable task coordination and update team members regarding everyone's working status.

Due to the increasing hardship in influencing and motivating followers in a virtual setting, investigators have found that leaders in a virtual environment can improve the team's self-management ability. They suggested focusing on development [26]. Such selfdirected teams are believed to have shared leadership; this refers to a process in which team members share responsibilities, mutually influence and direct each other, and represent a collaborative decision-making process [27]. Unlike traditional hierarchical leadership, shared leadership has a more lateral influence process rather than being up or down and is a form of collective effort that increases team performance [28].

In the context of a virtual atmosphere, shared team leadership complements traditional hierarchical leadership and structural supports while affecting group operation [27]. In fact, leaders can enable the development of shared leadership inside the team, while shared leadership can supplement formal leadership. Furthermore, the shared leadership that occurs in virtual teams is best described as task leadership. As such, appointed leaders still have the responsibility to build trusting relationships within virtual teams, facilitating the emergence of shared leadership and enhancing team performance.

Task-oriented behaviors of leaders towards individuals increase the motivation of members to put more effort in work-oriented activities. Specifically, leaders in virtual teams 
can initiate private conversations with each member via instant messaging or phone calls to understand their needs. Depending on members' different local environments, leaders may assist members in setting personalized business goals and establishing procedures for getting things done. Such behaviors of leaders are thought to be beneficial as they increase follower self-efficacy and work motivation [29]. Additionally, leaders may be required to provide budget support, equipment and feedback to their members.

In addition to counseling and supporting each member's duties, a virtual team leader can increase followers' love for them through relationship-oriented behaviors. The messages and behaviors of the leaders play an important role in the emotional reactions of the members [30]. In order to develop high-quality relationships with members, leaders can go beyond helping team members by exchanging social/personal information with each follower [31].

A solid underpinning must be constructed to achieve the most value and success from virtual teams. As long as the three success conditions are met, the team will continue to survive. The first of these conditions is the goal, the second is the clear definition of leadership responsibilities, and the final is the creation of the right team culture [32]. The factors that stand out as the success conditions of virtual teams are as follows [33]:

- Team building.

- Adaptation.

- Successful communication.

- Continuity of trust effect.

- Interaction.

- $\quad$ Effective information management.

- Leveraging and managing technology.

- Cultural dynamics management.

- Leadership influence and decent coaching.

- Effective coordination mechanism.

- Control system.

- Management of team performance.

- Project management and empowerment of the employees.

In their study, Malhotra, Majchrzak and Rosen recognized six leadership practices for effective leaders to master the challenges related to virtual teams. These are listed as follows [34]:

- $\quad$ Build and maintain trust using communication technology.

- Make sure that diversity is understood, appreciated and protected.

- Manage meetings and virtual work cycle.

- $\quad$ Observe team progress with technology support.

- Increase the visibility of virtual members inside and outside the team.

- Ensure that different participants of the virtual team benefit from the whole.

Focusing on the norms of how information is communicated, rethinking the communication model depending on team development (virtual meetups), and making progress open using the virtual team workspace are the main ways to build and maintain trust using communication technology. Creating a certain image, and protecting or changing that image, is one of the long-term strategies [35]. This strategy is achieved through communication technology. The virtual team leader has to protect the personal data of the team members, oversee the information of the employees and build trust with their members. Virtual teams often consist of individuals with different personalities, interests, experiences and communication styles. Therefore, the ability to benefit from the diversity of the team depends on the extent to which these individual differences are understood, used and appreciated.

An effective virtual team leader understands and appreciates distributed diversity; by creating virtual subgroups, using asynchronous electronic tools (e.g., electronic discussion threads) and allowing different views to be expressed [34]. Having virtual team meetings is 
very important as it serves to keep its members energetic about their work and synchronize with each other.

We can summarize certain ways virtual team leaders manage the virtual business lifecycle and meeting. These could be listed as making use of the starting moment of virtual meetings to create a social relationship, ensuring everyone's participation and getting news from them through various controls during the meeting, and allowing the minutes and future work plan to be sent to the team members at the end of the meeting [34].

Virtual team leaders carefully observe the team's online progress by evaluating electronic discussions, document submissions and involvement in virtual meetings. Progress is also observed by evaluating the usage of information technology to back the team. Monitoring team progress with the use of technology is possible by closely examining asynchronous (electronic discussions and document submissions in the knowledge pool) and synchronous communication models (virtual meeting participation and instant messages).

In addition, the researchers suggest a few more ways for effective virtual team leaders to implement the above-mentioned practices. Since it is difficult to evaluate goodwill in the virtual environment, it is seen that the feeling of trust in virtual teams is generally based on actions rather than goodwill [36]. Therefore, expectations for actions should be clear.

Yücebalkan (2003) conducted his research based on the idea of new management, which is becoming increasingly abstract [37]. According to him, virtual management, which is an understanding that responds to the needs of the world and breaks traditional patterns, is intertwined with the concepts of abstract, non-simple, emotional, fuzzy and variable. Yücebalkan composed his work in three parts; he discussed the concept of postmodernism in the first part, the postmodern-oriented virtual organizations in the second part, and the concept of leadership in virtual organizations in the last part. In the study of the first part, the historical development of post-modernity was formed from its basic concepts. Yücebalkan, who examined the weak and strong sides of virtual teams, post-modernist organizations that direct organizations to virtual organizations, and the systematic components of virtual organizations in the second part; in the last section, the destruction of the leader and team member component, the change of leadership style and virtual organizations are analyzed. In addition, he materialized the features of virtual leadership by defining virtual leadership as "synergic value that does not depend on the person or people, exists with the interactive interaction of people with virtual leadership characteristics and is revealed in the system". The aim of this study is to reveal different perspectives based on the perceptions and components of a small-scale team member in virtual businesses on a global scale, based on the level of ownership, which includes the basic characteristics of the virtual leadership type. He listed the findings in the survey study, which could not reach generalizations and definite judgments in items.

In his study, Naktiyok [38] discussed the leaders who use the virtual path in the leadership process in organizations and the leaders who do not use the virtual path in terms of characteristics and attitudes. In his study, he examined the differences and similarities between the traditional leader and the virtual leader. He analyzed the period when the traditional economic system was replaced by the global economic system with the development of information and communication technologies in terms of leaders, companies and team members. He started the survey study with a meeting where leadership characteristics could be discussed and invited the leaders of ten organizations.

At the end of the meeting, 73 different leader characteristics, attitudes and abilities were determined by the answers of the ten leaders. Twenty-two leadership traits and twenty leadership attitudes and abilities that leaders agreed upon were identified. In the survey study, questions about whether the organizations are virtual organizations or not were also included. As a result of the research, it has been determined that virtual leaders are based on attitudes and abilities such as global ideas, sharing information, using technology, vision and decision making. On the other hand, it has been found out that those traditional leaders have features such as stating the purpose, being sensitive to thoughts and feelings and not compromising their values. 
Maduka et al. [39] emphasized in their study that the use of virtual teams in the current business world is increasing. They stated that leaders in virtual teams should be aware of certain special competencies and that they should instill competencies in their members. In this context, they conducted face-to-face structured interviews with 14 participants in two virtual team groups, using a questionnaire designed after the literature review, in order to determine the skills required for effective leadership in virtual teams.

The interviews were designed to illuminate the views and perceptions of virtual team members according to the characteristics of virtual team leaders. The answers obtained were analyzed using descriptive statistics and thematic analysis. According to the emerging findings, when considering virtual leadership competencies, it was concluded that virtual team leaders do not perform well in general because they lack a few of the capabilities essential for effective leadership in the context of a virtual team.

In their study, Çırpan and Yomralığlu [40] investigated how virtual teams have become indispensable in global organizations with the intense use of technology. With the coronavirus epidemic, which has been experienced since 2019, the effect of virtual teams being the only way for the working environment has been stated in the research. They analyzed leadership characteristics that affect high performance from the perspective of the leader and team members. Qualitative data were obtained through interviews with five virtual team leaders and five team members of ten people in separate organizations. The main features of virtual teams for high performance are the effectiveness of communication, accessibility of infrastructure, trust in the team and clear definition of job descriptions. In the study, it was emphasized that the harmony between team members who are not from similar cultures is also important. Using content analysis, which is known as a process that is blended with the improvement of multiple reality and personal perceptions, as data analysis, they initially chose to write the audio recordings. They used two encodings, leaders and members, and carefully read the data for comprehensive opinion analysis. By cross-checking the perspectives of organization members and leaders, they accepted the common points of different experiences and perceptions as prominent factors for high-performance virtual teams. They determined the most important codes according to hierarchical order. They reported the results with the consensus of the researchers.

\section{Results of Focus Group Studies and Scale Development}

In this research carried out in order to create a valid and reliable scale, which is different from the leadership scales existing in the academic literature, in a manner to focus on global virtual environments, the item pool that forms the basis of the scale was produced by using focus group interviews and expert opinions in line with literature reviews. After the item pool was produced, scale questions were developed, expert opinions were sought, and a pilot application was conducted with 123 participants for multinational company employees in the Marmara region of Turkey.

\subsection{Focus Group Interviews}

Focus group interviews are one of the methods commonly used in qualitative research. Researchers argue that focus group interviews emerged because researchers sought alternative new methods to overcome the deficiencies of traditional in-depth interviews [41]. According to Morgan, focus group discussion is a research technique in which data is collected through group interaction on a subject determined by the researcher [42].

In the 1950s, focus group interviews were widely used in the business sector by market researchers to evaluate consumer opinions about home appliances, develop brand identity, design product packaging and measure marketing strategies [41]. In the 1980s, focus group studies began to emerge in social science research.

Focus group interviews, which are frequently used in exploratory research today, are a qualitative information-gathering tool and a carefully planned discussion-interview method in which qualitative and observational data are collected through group interaction; it is carried out with small groups in order to obtain in-depth information and generate thoughts 
on a topic determined by the researcher, accompanied by a moderator, as defined in [42,43]. Hennink and Hunter [44] developed a description of an interactive discussion between six and eight preselected participants focused on a specific topic, led by a knowledgeable moderator. The purpose of focus group interviews is to obtain a wide range of ideas about the research topic within 60-90 $\mathrm{min}$ and to form an environment in which participants feel comfortable while articulating their views [44].

A typical focus group discussion consists of a small number of participants with the guidance of a skilled moderator. In such interviews, the task of the moderator is to effectively reveal the ideas and thoughts of the other group members participating in the interview on the current topic. In his study, Krueger [43] recommends that the number of people to be included in the focus group should not be more than seven in order to avoid complex problems.

In this study, first of all, comprehensive research was conducted on the subject of the scale to be developed. As a result of the researches and examinations, questions were developed to be used in focus group interviews. While paying attention to the clarity of the open-ended questions, the order of the questions was made from general to specific. At another stage, a focus group meeting was planned with the people who were asked to participate. After the interviews were carried out at the predetermined place and time, the audio and video recordings were analyzed and item analyses were carried out. After the researcher's item analysis, the item pool was finalized by using the opinions of three experts in the field.

Focus group interviews conducted in this paper were used to create a research design. The draft scale was developed with the support of the item pool created as a result of focus group discussions. While paying attention to the fact that the questions in the draft scale are clear and understandable, taking into account the recommendations in the literature, attention was paid to ensure that the number of questions was not more than 50 in order not to bore the participants.

\subsection{Item Pool Generation}

In the first step, which is commonly called "creating an item pool", the researcher obtains theoretical support [45]. It is possible to classify item pooling methods as deduction, induction or a combination of both. The deductive method includes creating an item pool based on a comprehensive literature review and pre-existing scales [46]. On the other hand, creating an item pool with the inductive method is based on qualitative information about a structure that emerges from the views obtained from the target population. Focus groups, interviews and expert panels are among the techniques used in the inductive method [47].

In the second step, which is usually called "theoretical analysis", the researcher evaluates the content validity of the new scale and ensures that the created item pool reflects the desired structure [48]. It is an important step as inferences about the final scale items are made through content validity. To gain confidence in all resulting inferences, the item content must be considered valid. The researcher can get support from expert opinions or potential participants of the scale in order to ensure content validity.

In the last step, consisting of the statistical analysis, the researcher evaluates whether the new scale has structural validity and reliability. Construct validity is directly associated with the question of what the measurement tool actually measures. It is possible to measure construct validity with exploratory factor analysis, confirmatory factor analysis or convergent, discriminant, predictive, criterion, internal and external validity. In contrast, reliability is a measure of score consistency, which is generally measured by the use of internal consistency, retest reliability, item-total correlation/inter-item reliability and interobserver reliability [49]. To guarantee construct validity and reliability, data must be collected in the form of a reasonably large and appropriately chosen sample representative of the target population.

These difficulties in the scale development process deteriorate the statistical analysis results obtained, limit the future potential of the novel scale and prevent its generalizability. 
In this sense, as a result of the most frequently occurring issues, the study is essential in providing essential information that will help develop best practices for future research. In this study, first of all, a detailed literature review about leadership scales was made. Academic studies and focus group discussions have been used to create an item pool. After creating separate item pools for each focus group, the items suitable for the scale were included in the study or redesigned to be appropriate for the subject, and the item pool took its final form.

In the current study, both methods were used together at the stage of creating the item pool. In the first stage of the research, studies on leadership styles were examined. Attention was paid to the research methods, aims and scopes, validity and reliability levels of the examined studies as well as the dimensions of the scale items. Subsequently, focus group interviews were conducted in order to create statements about the concept of virtual team leadership. During the focus group discussions, pre-formed open-ended questions were asked to the participants. While it is recommended that the questions asked to the participants be clear and understandable during the focus group discussion, it is also important that the answers are in the form of mutual communication. It is also important to ask questions in order from general to specific. At this point, the ideas and thoughts of the participants will mature and more logical answers will emerge. The types of questions to be used in focus group interviews are generally under five main headings and are categorized as: opening, introduction, transition, key and finishing questions [50]. The questions posed to the participants in the current study are presented in the table below. Table 1 provides the focus group questions which are determined by the review of the literature and the personal expertise of the two contributing authors of this study.

Table 1. Focus Group Interview Questions.

\begin{tabular}{cc}
\hline Question Type & \multicolumn{1}{c}{ Questions } \\
\hline Opening & To what extent are virtual communication tools included in your daily life? \\
\hline - & $\begin{array}{l}\text { Let's say you hold a meeting about your job or education in a virtual environment. When we } \\
\text { evaluate the management style in such meetings in the context of leadership types, we come }\end{array}$ \\
Introduction & across the concept of virtual team leadership. \\
& $-\quad$ What do you think a virtual team is? \\
& $-\quad$ What do you understand when you say virtual team leadership?
\end{tabular}

Think about the meetings you hold in the virtual environment in terms of leadership styles and management styles.

- How do you think a team leader in a virtual environment should be?

Transition - What are the features that distinguish a virtual team leader from other leaders?

- How would a virtual team leader be expected to motivate their followers?

- How does the virtual team leader monitor or monitor team members' performance and progress towards task completion?

- How do you define the concept of virtual team leadership in multinational companies?

- Do you think that virtual meetings held in multinational companies are different from

Key face-to-face meetings? If so, what are they?

- What do you think is the role of the leader in virtual meetings of multinational companies? Does the leader in face-to-face meetings have common aspects and differences with his duties? If so, what are they?

- Could you share what you would like to add to the topic of virtual team leadership in

Closing multinational companies?

- Is there a topic that we skipped, didn't talk about, or didn't care much about?

In the research, a total of three focus group interviews were conducted and each interview was recorded. The first focus group meeting was held with the participation of seven people working within the multinational company. The interview was held in the 
company's meeting room. The second was carried out with a group of five academicians. Since the interview could not be held face-to-face due to the coronavirus epidemic, it was completed via the online platform. The third focus group meeting was held via the online platform, in the same way with the students who are continuing their graduate education in the field of international trade and finance. As a result of the examination of the recorded documents, separate item pools were created for each focus group. The results of open-ended questions and the number of occurrences (frequency) are given in Tables 2 and 3.

Table 2. First Focus Group Frequencies.

\begin{tabular}{|c|c|c|c|}
\hline Topic & Freq. & Topic & Freq. \\
\hline Problem Solving Skills & 4 & Orderly & 2 \\
\hline High responsibility & 2 & Solution oriented & 4 \\
\hline Results oriented & 5 & Success oriented & 1 \\
\hline Observation skills & 3 & Fair in assigning order of speech & 5 \\
\hline High coordination skills & 10 & Positive speech & 1 \\
\hline Authoritarian & 8 & Presentable & 5 \\
\hline Lack of Authority & 4 & Orientation Appropriate for the Environment & 3 \\
\hline Emphasis on Equality & 7 & Realistic and Brave & 8 \\
\hline Eliminates boredom & 8 & Fake & 2 \\
\hline Clarity & 4 & Presentation environment & 8 \\
\hline Attentive to environment & 1 & Difficult communication with members & 4 \\
\hline Ability to keep the members in the meeting & 1 & Collaboration among members & 4 \\
\hline Ability to object & 4 & Gifts, rewards & 4 \\
\hline Difficulty to object & 2 & Being Concise & 2 \\
\hline Prepares environment for the meeting & 2 & One to one Behavior, fusing the group & 5 \\
\hline Interactive & 6 & Meeting Management with the Participant & 3 \\
\hline One to one attention & 3 & Question and Answer Management & 3 \\
\hline Praises success & 3 & Enables members to report & 1 \\
\hline Not Voicing Members' Failures & 5 & Punishment & 1 \\
\hline Knowledge of foreign language & 5 & One to one criticism & 4 \\
\hline High knowledge in area & 11 & High communication skills & 3 \\
\hline Enables consensus & 8 & Charismatic & 3 \\
\hline Knows people & 6 & Male & 3 \\
\hline High Internet Speed & 3 & Female & 2 \\
\hline Clear Job Definitions & 8 & Dynamic & 3 \\
\hline Sympathetic, Fun & 7 & Low Job Satisfaction & 4 \\
\hline Gives importance to privacy and availability & 11 & Members Distraction & 2 \\
\hline Information before meetings & 5 & Assigns jobs according to skills & 3 \\
\hline Conflict detection and resolution & 3 & Sets targets & 2 \\
\hline Self Confidence & 2 & & \\
\hline Total & & & 246 \\
\hline
\end{tabular}


Table 3. Second Focus Group Frequencies.

\begin{tabular}{|c|c|c|c|}
\hline Topic & Freq. & Topic & Freq. \\
\hline Delegating responsibility & 3 & Short targets & 4 \\
\hline Coordination & 6 & Frequent Evaluation Meetings & 4 \\
\hline Follow-up & 1 & Project Based Consultant Assignment & 2 \\
\hline Goal oriented & 9 & Gifts, Surprises & 1 \\
\hline Organizing & 6 & Short presentations & 4 \\
\hline Motivation & 1 & Lack of symbols & 2 \\
\hline Virtual leader same as face to face leader & 3 & Advanced technology & 4 \\
\hline Virtual leader different than face to face leader & 4 & Meeting Hours Suitable to Members & 2 \\
\hline Resolves conflict & 4 & Reflects success on wages & 3 \\
\hline Assigns Work appropriately & 7 & Change in concept of work leave & 1 \\
\hline Making decisions together & 1 & Flexible & 1 \\
\hline Exchange of ideas & 3 & Leader takes part of work & 1 \\
\hline Making sure not to deviate from the subject & 4 & Advising & 2 \\
\hline Technical skills & 4 & Awareness of Cultural Differences & 1 \\
\hline Young & 3 & Effective Management of Time Differences & 5 \\
\hline Success oriented & 1 & Communication skills & 5 \\
\hline Divides team into small groups & 10 & Authoritarian & 1 \\
\hline Divides work into micro packets & 7 & Low cost & 1 \\
\hline Rule setter & 6 & Leader's Characteristics are Highlighted & 4 \\
\hline Written duties & 4 & Order of talking & 3 \\
\hline Clear work definition & 4 & Prevents arguments & 3 \\
\hline Detailed work follow up & 5 & Planned and organized meting management & 2 \\
\hline Increase in formality & 3 & & \\
\hline Total & & & 155 \\
\hline
\end{tabular}

When the item pools that emerged as a result of the focus group interviews carried out on behalf of the research are examined, it is seen that the most recurring subjects in the first group are the concepts of a high level of knowledge and caring for private life. In the second focus group interview, the concept with the highest frequency of repetition was teams being divided into small groups. In the third focus group discussion, in Table 4 below, it is seen that the word "directing" has the highest number of repetitions. 
Table 4. Third Focus Group Frequencies.

\begin{tabular}{|c|c|c|c|}
\hline Topic & Freq. & Topic & Freq. \\
\hline Directing & 9 & Ability to procrastinate & 1 \\
\hline Purposeful Acting & 3 & Voice pitch & 8 \\
\hline Sets targets & 1 & Unexpected questions & 5 \\
\hline Increases group harmony & 6 & Struggler & 1 \\
\hline Authoritarian & 8 & Making Missions Matter & 1 \\
\hline Trust & 1 & Fun environment & 2 \\
\hline Role model & 2 & Include Important People in the Meeting & 1 \\
\hline Leader is assigned & 3 & Before the meeting mentions the purpose of the meeting & 4 \\
\hline Dynamic Environment Provider & 3 & Culture & 2 \\
\hline Just & 1 & Language knowledge & 5 \\
\hline Technology & 6 & Open to innovation & 2 \\
\hline Maintains order & 2 & Appreciates the members & 3 \\
\hline Knowledge & 2 & Proper meeting time & 1 \\
\hline Knows members & 2 & Short meeting & 1 \\
\hline Style of speech & 1 & Difficulty to settle conflict & 9 \\
\hline Gestures, Mimics & 5 & Ability to reach after meeting & 1 \\
\hline High degree of responsibility & 1 & High feedback & 1 \\
\hline Face to face meeting leader is more effective & 2 & Instantly Changes The Subject during conflict & 1 \\
\hline Flexible timing & 2 & Analytical & 3 \\
\hline Loss of time (Virtual Meeting) & 4 & Sets the rules before the meeting & 1 \\
\hline Appearance & 1 & Including everyone in the subject & 2 \\
\hline Low efficiency & 4 & Order of Speech & 3 \\
\hline High efficiency & 5 & Using one technological tool & 1 \\
\hline Low cost & 1 & Contribution to Salary with Point System & 2 \\
\hline Number of people & 2 & Meeting environment order & 5 \\
\hline Easy to lead virtual teams & 2 & Must prevent commotion & 2 \\
\hline Difficult Person & 6 & Setting Meeting Times According to Majority & 1 \\
\hline Difficulty exercising authority & 5 & Talkative & 1 \\
\hline Short Duties & 2 & & \\
\hline Total & & & 162 \\
\hline
\end{tabular}

\subsection{Making Use of Expert Opinions}

With this draft scale, the opinions of three experts in the field were consulted in order to determine the characteristics of virtual team leaders in multinational companies and the clarity of the items in the scale. In line with the answers of the experts, the items with weak representation were corrected or deleted and rewritten. In this context, the five items in the scale created by the researcher were divided into two, some expressions were rearranged for easier understanding, and expressions with the same meaning were removed from the scale. As a result, the number of items, which was 43 at the beginning, was reduced to 36 based on expert opinions. In line with the opinions obtained, the final items were decided and the final form of the draft scale was created. The content validity of the measurement tool that emerged as a result of the procedures needed to be ensured. Thus, a pre-application form was designed for the pilot application to be carried out before 
the reliability and validity analysis of the scale. The 36-question survey is provided in Appendix A. The questions make use of a 5-point Likert-type agreement scale. A similar procedure was carried out by Gencer and Akkucuk [51] and well documented.

\subsection{Pilot Study and Reliability and Validity Assessment}

Testing the draft scale created in scale development studies on a smaller sample before applying it to the population is a method used for newly developed scales. This method, which is called a pilot application, is also used to determine what kind of effects the previously developed scales will have on different samples [52]. In this context, it is possible to eliminate answering and different out-of-sample defects that reveal a large part of the total survey error through the pilot study [53].

While the universe of the current study is all teams in virtual environments, its sample is employees of multinational companies located in the Marmara region of Turkey.

If confirmatory factor analysis is performed in scale development studies, it is recommended that the number of people participating in the research be two times more than the number of items in the scale, while when the literature is examined, it is seen that the sample used for the pilot application is considered to be between 100-200 people [54]. In this context, it is possible to say that the sample size of 123 is suitable for the pilot study, since only exploratory factor analysis will be carried out in the current study. In addition, the convenience sampling method was used to perform the sample selection of the study. The selected group members were part of the close circles of the members of the academic community at the universities where the researchers worked and the family businesses that they were associated with. However, all worked in multinational companies and had the chance to work in remote groups due to their work, especially after the pandemic. Statistics regarding the demographic information of the people who participated in the survey are given in Table 5 .

Table 5. Pilot Study Participants.

\begin{tabular}{|c|c|c|c|}
\hline Variables & & Frequency & $\%$ \\
\hline \multirow{3}{*}{ Gender } & Female & 49 & 39.8 \\
\hline & Male & 74 & 60.2 \\
\hline & Total & 123 & 100 \\
\hline \multirow{6}{*}{ Age } & $18-24$ & 16 & 13 \\
\hline & $25-34$ & 63 & 51.2 \\
\hline & $35-44$ & 34 & 27.6 \\
\hline & $45-54$ & 8 & 6.5 \\
\hline & $55+$ & 2 & 1.6 \\
\hline & Total & 123 & 100 \\
\hline \multirow{6}{*}{ Education } & Elementary & 1 & 0.8 \\
\hline & High School & 17 & 13.8 \\
\hline & BA/BS Degree & 80 & 65 \\
\hline & MA/MS Degree & 24 & 19.5 \\
\hline & Doctorate & 1 & 0.8 \\
\hline & Total & 123 & 100 \\
\hline \multirow{7}{*}{ Province } & Yalova & 30 & 24.4 \\
\hline & Bursa & 23 & 18.7 \\
\hline & İstanbul & 49 & 39.8 \\
\hline & Tekirdağ & 11 & 8.9 \\
\hline & Kocaeli & 6 & 4.9 \\
\hline & Balıkesir & 4 & 3.3 \\
\hline & Total & 123 & 100 \\
\hline
\end{tabular}




\subsection{Reliability and Validity Assessment}

It is possible to define reliability as the consistency between the answers given by the participants to the items in the scale. The concept of reliability, which is related to the errors in the measurement, expresses how accurately the phenomenon to be analyzed is measured. If the amount of error in the measurement related to the study is low or absent, the reliability is considered high. Reliability analyses are considered indispensable in scale development studies and must be done correctly.

Cronbach's Alpha Reliability: With this method, a reliability coefficient is calculated on the answers given by the participants in a single application. While the Cronbach Alpha Coefficient is between 0 and 1 , if this value is close to zero, the scale is unreliable, and if it approaches one, it means that the degree of reliability increases.

This coefficient is expected to be above 0.7. Satisfactory Cronbach Alpha Coefficient is 0.8 and above. To measure the internal consistency of the measurement tool in this study, the "Cronbach Alpha Coefficient" was examined in order to analyze the analysis. The result is that this survey gives a reliability of 0.94 which can be considered satisfactory.

In addition, the component loadings can be used to name the dimensions consisting of the 36 items in the item pool and to purify the scale by eliminating some unnecessary items. We believe that 6 dimensions containing 29 items from the original 36 items explain $60 \%$ of the variation. Table 6 provides the results of the loadings obtained through Varimax rotation. The deleted items are items 4, 13, 17, 29, 31, 33 and 34. The justification for the deletion is that the item loadings are below $10 \%$ for all dimensions. After the deletion, Cronbach's Alpha turns out to be 0.913 which is also considered satisfactory for the 29-item purified scale. The individual dimension Cronbach's Alpha values were also calculated. Dimension 1 Managerial Qualities had a Cronbach's Alpha value of 0.852, Dimension 2 Interactivity had a Cronbach's Alpha value of 0.764, Dimension 3 human Relations had a Cronbach's Alpha value of 0.770, Dimension 4 Personal Traits had a Cronbach's Alpha value of 0.753 , Dimension 5 Rewards had a Cronbach's Alpha value of 0.665 , and finally Dimension 6 Flexibility had a Cronbach's Alpha value of 0.616 . When it comes to the eigenvalues of the dimensions interpreted from the analysis (rotation sum of squares) we have the following results: Dimension 1 has an eigenvalue of 4.141 explaining a cumulative variance of \% 14.281, Dimension 2 has an eigenvalue of 3.345 explaining a cumulative variance of \% 25.817, Dimension 3 has an eigenvalue of 2.788 explaining a cumulative variance of \% 34.431, Dimension 4 has an eigenvalue of 2.603 explaining a cumulative variance of \% 44.406, Dimension 5 has an eigenvalue of 2.473 explaining a cumulative variance of \% 52.934, Dimension 6 has an eigenvalue of 1.961 explaining a cumulative variance of \% 59.695 .

Table 6. Rotated Component Matrix with Dimension Names.

\begin{tabular}{|c|c|c|c|c|c|c|}
\hline & Managerial Qualities & Interactivity & Human Relations & Personal Traits & Rewards & Flexibility \\
\hline Item 19 & 0.736 & & & & & \\
\hline Item 15 & 0.734 & & & & & \\
\hline Item 20 & 0.705 & & & & & \\
\hline Item 18 & 0.688 & & & & & \\
\hline Item 21 & 0.662 & & & & & \\
\hline Item 23 & 0.623 & & & & & \\
\hline Item 24 & 0.581 & & & & & \\
\hline Item 14 & 0.346 & & & & & \\
\hline Item 25 & & 0.717 & & & & \\
\hline Item 28 & & 0.689 & & & & \\
\hline Item 26 & & 0.618 & & & & \\
\hline Item 16 & & 0.572 & & & & \\
\hline Item 27 & & 0.531 & & & & \\
\hline Item 22 & & 0.518 & & & & \\
\hline
\end{tabular}


Table 6. Cont.

\begin{tabular}{|c|c|c|c|c|c|c|}
\hline & Managerial Qualities & Interactivity & Human Relations & Personal Traits & Rewards & Flexibility \\
\hline Item 3 & & & 0.723 & & & \\
\hline Item 35 & & & 0.696 & & & \\
\hline Item 36 & & & 0.627 & & & \\
\hline Item 32 & & & 0.579 & & & \\
\hline Item 8 & & & 0.493 & & & \\
\hline Item 10 & & & 0.423 & & & \\
\hline Item 7 & & & & 0.853 & & \\
\hline Item 6 & & & & 0.796 & & \\
\hline Item 30 & & & & 0.549 & & \\
\hline Item 12 & & & & & 0.737 & \\
\hline Item 9 & & & & & 0.691 & \\
\hline Item 11 & & & & & 0.659 & \\
\hline Item 1 & & & & & & 0.804 \\
\hline Item 2 & & & & & & 0.726 \\
\hline Item 5 & & & & & & 0.497 \\
\hline
\end{tabular}

\section{Discussion}

Changes in market and business structures as a result of developments in information and communication technologies have become a subject that needs to be examined within the scope of virtual organizations, especially in terms of leadership characteristics. With the fast change in technology, communication technology has developed and the level of communication has increased through virtual communication tools. In the current order, people, regardless of status, access and use data they need with the help of information and communication technologies. With the increase in the level of digitalization in the world, many businesses have started to use virtual communication tools at a high level. As a result, the concept of the virtual team has emerged. Virtual teams work beyond the boundaries of time and space, using communication media such as e-mail, telephone, groupware and video conferencing, and consist of members in more than one physical location.

Organizations achieve great gains by overcoming geographical, cultural and temporal differences thanks to virtual teams. Multinational companies, which are organizations that operate in more than one country, have central controls for all parts of the company and control small company units in other countries, are also among the organizations that create virtual teams using Internet-mediated communication tools.

The desired leadership characteristics are not constant and changes are observed over the years [55] therefore it is important to update the current literature with newer studies. Leadership style is an important concern for companies as leadership styles may also influence organizational commitment [56] and employee expectations of the superiors [57]. It is also important to note that, as also stated by Oc [58], "leadership does not occur in vacuum". It is important to point out the fact that leaders should adopt their styles based on the unique needs and expectations of the situation and the employees.

With the current study, it is aimed to develop a valid and reliable scale in order to discover and analyze the virtual team leadership characteristics of individuals within the multinational company. At this point, firstly, the concepts of leadership, multinational companies and virtual team leadership are explained. Literature, focus group discussions and statistical analyzes were used to develop the items to be included in the scale to be created afterwards. For the research, a total of three focus group interviews were conducted and the data obtained were analyzed. In order to ensure the content validity of the items that emerged as a result of the data analysis, expert opinions were consulted and a 29-item scale was created.

After the scale to be used for the study was established, a pilot study was carried out on a sample of 123 employees of multinational companies located in the Marmara region. The results obtained with the factor analysis studies carried out in order to measure the construct validity of the results obtained as a result of the pilot application are listed. 
In this study, it has been our goal to obtain a valid and reliable measurement tool by considering the perception of employees in multinational companies in order to approach the phenomenon of leadership from a different perspective and to determine the characteristics of the leader in the virtual environment. It is thought that the research will be useful to measure the concept of virtual team leadership, which does not have many resources in the literature. When the literature on the research subject is examined, no study has been found that deals with the relationship between the concepts of multinational companies and virtual team leadership. At this point, it is possible to say that the work that emerged has an exploratory character.

\section{Conclusions}

When the literature is examined, it is seen that there is no scale development study on virtual team leadership. Previous research on the subject is generally comprised of qualitative studies. It is worth mentioning that this research was conducted to elucidate the concept of virtual team leadership, to try to define it and to determine its features.

It is also seen that the research has some limitations in terms of the methods and sample size. First, the qualitative data collection part of the study was completed by making use of the literature and focus group interviews. Due to the coronavirus epidemic, two of the focus group meetings were held remotely. However, since only the pilot study was carried out in the research, the sample was narrowed and the survey data were obtained with the participation of multinational company employees in the Marmara region of Turkey. Although the current limitations pose difficulties for the generalizability of the research, the results show that the scale is valid and reliable. Furthermore, as per the sample size of 123 used in calculating the Cronbach's Alpha of the scale, we realize we are on the lower side of sample size requirements and therefore more thorough analyses of the empirical properties of the scale are left for a larger study.

It is supposed that scales created without considering the characteristics of the leaders in the virtual environment are insufficient to explain this concept. Thanks to this developed scale, it will be possible to measure the leadership characteristics of individuals working in multinational companies in the virtual environment. We believe this scale can stimulate a series of academic research studies on this field. These studies may further the empirical analyses by larger samples or create different spin-off scales applicable to different cultures or working environments. On the applied side, when it comes to company administration it may also be used as a scale in the human resources departments. Moreover, as resource considerations are becoming more important for businesses in terms of sustainability [59], doing business remotely will be ever more important. In addition, it is expected that this scale, called the GVTLS Scale, which we have added to the literature, will be a pioneer in leadership in virtual teams in different regions of the world and in various sectors, and its results will be shared with the academic community.

Author Contributions: Conceptualization, S.N.B. and Y.G.G.; methodology, Y.G.G.; software, S.N.B.; validation, S.N.B., Y.G.G. and U.A.; formal analysis, S.N.B.; investigation, S.N.B.; resources, S.N.B.; data curation, S.N.B.; writing—original draft preparation, S.N.B.; writing-review and editing, Y.G.G. and U.A.; visualization, U.A.; supervision, U.A.; project administration, Y.G.G. All authors have read and agreed to the published version of the manuscript.

Funding: This research received no external funding.

Institutional Review Board Statement: The study was conducted according to the guidelines of the Declaration of Helsinki, and approved by the Institutional Review Board (or Ethics Committee) of YALOVA UNIVERSITY (protocol code 2021/47 and 2 May 2021).

Informed Consent Statement: Informed consent was obtained from all subjects involved in the study.

Data Availability Statement: The data presented in this study are available in the article.

Conflicts of Interest: The authors declare no conflict of interest. 


\section{Appendix A}

Table A1. 36 Item Survey GVTLS Applied to Sample of 123 Respondents. (x) Indicates 7 Items Deleted as a Result of Factor Analysis.

\begin{tabular}{|c|c|c|c|c|c|c|}
\hline & Virtual Team Leader & 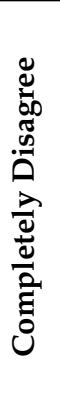 & 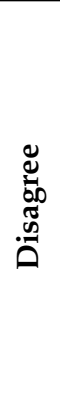 & 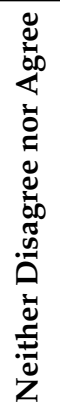 & 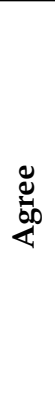 & 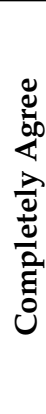 \\
\hline 1 & $\begin{array}{l}\text { Has information about different cultures and effectively } \\
\text { manages cultural differences within the team. }\end{array}$ & 1 & 2 & 3 & 4 & 5 \\
\hline 2 & $\begin{array}{l}\text { Determines the meeting time, taking into account the } \\
\text { availability and private lives of the team members. }\end{array}$ & 1 & 2 & 3 & 4 & 5 \\
\hline 3 & $\begin{array}{l}\begin{array}{l}\text { Designs the meeting environment according to the nature } \\
\text { of the work. }\end{array}\end{array}$ & 1 & 2 & 3 & 4 & 5 \\
\hline $4(x)$ & $\begin{array}{l}\text { During the meeting in the virtual communication tool } \\
\text { and in the virtual environment, pays attention to } \\
\text { his/her appearance. }\end{array}$ & 1 & 2 & 3 & 4 & 5 \\
\hline 5 & $\begin{array}{l}\text { With team members from different countries, has a } \\
\text { command of the common language used to } \\
\text { communicate. }\end{array}$ & 1 & 2 & 3 & 4 & 5 \\
\hline 6 & His/her communication skills are high. & 1 & 2 & 3 & 4 & 5 \\
\hline 7 & $\begin{array}{l}\text { Uses gestures, facial expressions and tone of } \\
\text { voice effectively. }\end{array}$ & 1 & 2 & 3 & 4 & 5 \\
\hline 8 & $\begin{array}{l}\text { By creating virtual sub-teams and making use of } \\
\text { asynchronous electronic means (e.g., electronic discussion } \\
\text { threads) allows different opinions to be expressed. }\end{array}$ & 1 & 2 & 3 & 4 & 5 \\
\hline 9 & $\begin{array}{l}\text { Has high technical knowledge about the virtual } \\
\text { communication tool he/she uses. }\end{array}$ & 1 & 2 & 3 & 4 & 5 \\
\hline 10 & $\begin{array}{l}\text { Gives one-to-one attention to team members and praises } \\
\text { their personal achievements. }\end{array}$ & 1 & 2 & 3 & 4 & 5 \\
\hline 11 & $\begin{array}{l}\text { Does not publicly express the failures of his/her team } \\
\text { members, but makes his/her criticisms one-to-one. }\end{array}$ & 1 & 2 & 3 & 4 & 5 \\
\hline 12 & $\begin{array}{l}\text { Ensures that individual achievements are reflected in } \\
\text { the salary. }\end{array}$ & 1 & 2 & 3 & 4 & 5 \\
\hline $13(x)$ & Organizes planned and regular evaluation meetings. & 1 & 2 & 3 & 4 & 5 \\
\hline 14 & $\begin{array}{l}\text { Appoints project-based consultants by dividing the team } \\
\text { into small groups. }\end{array}$ & 1 & 2 & 3 & 4 & 5 \\
\hline 15 & $\begin{array}{l}\text { Keeps the meeting time short and makes the } \\
\text { environment fun. }\end{array}$ & 1 & 2 & 3 & 4 & 5 \\
\hline 16 & $\begin{array}{l}\text { Sets short goals and breaks work down into } \\
\text { micro-packages. }\end{array}$ & 1 & 2 & 3 & 4 & 5 \\
\hline $17(\mathrm{x})$ & $\begin{array}{l}\text { Recognizes team members and distributes work } \\
\text { according to their abilities. }\end{array}$ & 1 & 2 & 3 & 4 & 5 \\
\hline 18 & Allows team members to submit work reports. & 1 & 2 & 3 & 4 & 5 \\
\hline 19 & $\begin{array}{l}\text { Holds the meeting by exchanging views with } \\
\text { team members. }\end{array}$ & 1 & 2 & 3 & 4 & 5 \\
\hline
\end{tabular}


Table A1. Cont.

\begin{tabular}{|c|c|c|c|c|c|c|}
\hline & Virtual Team Leader & 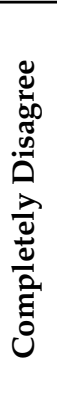 & 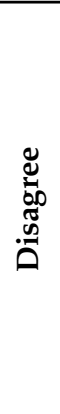 & 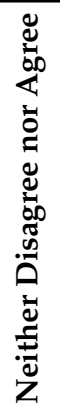 & 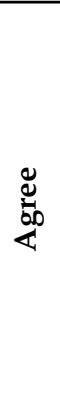 & 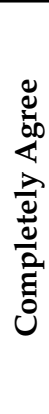 \\
\hline 20 & Coordinates and directs the team. & & & & & \\
\hline 21 & Delegates and monitors work. & 1 & 2 & 3 & 4 & 5 \\
\hline 22 & $\begin{array}{l}\text { Becomes a role model for its members by being a partner } \\
\text { in business. }\end{array}$ & 1 & 2 & 3 & 4 & 5 \\
\hline 23 & Activates all team members in the meeting. & 1 & 2 & 3 & 4 & 5 \\
\hline 24 & $\begin{array}{c}\text { Eliminates the distracting elements around the meeting } \\
\text { during the meeting. }\end{array}$ & 1 & 2 & 3 & 4 & 5 \\
\hline 25 & $\begin{array}{l}\text { Mentions the aims and rules of the meeting before the } \\
\text { meeting. }\end{array}$ & 1 & 2 & 3 & 4 & 5 \\
\hline 26 & $\begin{array}{c}\text { Gives the team members the right to speak at the } \\
\text { required level. }\end{array}$ & 1 & 2 & 3 & 4 & 5 \\
\hline 27 & Allows members to reach consensus. & 1 & 2 & 3 & 4 & 5 \\
\hline 28 & $\begin{array}{l}\text { Takes precautions by sensing the conflict that may arise } \\
\text { in advance. }\end{array}$ & 1 & 2 & 3 & 4 & 5 \\
\hline $29(x)$ & Is a goal setter and success oriented. & 1 & 2 & 3 & 4 & 5 \\
\hline 30 & Is open to innovations. & 1 & 2 & 3 & 4 & 5 \\
\hline $31(x)$ & Has the ability to solve problems & & & & & \\
\hline 32 & Friendly and fun. & 1 & 2 & 3 & 4 & 5 \\
\hline $33(x)$ & Has a high sense of responsibility. & 1 & 2 & 3 & 4 & 5 \\
\hline $34(x)$ & Observation and analysis skills are at a high level. & 1 & 2 & 3 & 4 & 5 \\
\hline 35 & Authoritarian and rule maker. & 1 & 2 & 3 & 4 & 5 \\
\hline 36 & $\begin{array}{c}\text { With his/her appearance and characteristics adapts to } \\
\text { the environment. }\end{array}$ & 1 & 2 & 3 & 4 & 5 \\
\hline
\end{tabular}

\section{References}

1. Ale Ebrahim, N.; Ahmed, S.; Taha, Z. Virtual Teams: A Literature Review. Aust. J. Basic Appl. Sci. 2009, 3, $2653-2669$.

2. Hertel, G.T.; Geister, S.; Konradt, U. Managing virtual teams: A review of current empirical research. Hum. Resour. Manag. Rev. 2005, 15, 69-95. [CrossRef]

3. Yanık, O.; Naktiyok, A. Etik Liderliğin Çalışanların İș Tatminine, Örgütsel Bağlılığına Ve İşten Ayrılma Niyetine Etkisinde Örgütsel Güven Ve Örgütsel Adalet Algısının Aracı Rolü. Bartın Üniversitesi İktisadi ve İdari Bilimler Fakültesi Dergisi 2017, 8 , 297-324.

4. Kuscu, M.; Arslan, H. Virtual Leadership At Distance Education Teams. Turk. Online J. Distance Educ. 2016, 17, 136-156. [CrossRef]

5. Balkaya, S.; Akkucuk, U. Adoption and Use of Learning Management Systems in Education: The Role of Playfulness and Self-Management. Sustainability 2021, 13, 1127. [CrossRef]

6. Sasmaz, M.U.; Sakar, E.; Yayla, Y.E.; Akkucuk, U. The Relationship between Renewable Energy and Human Development in OECD Countries: A Panel Data Analysis. Sustainability 2020, 12, 7450. [CrossRef]

7. Sasmaz, M.U.; Karamıklı, A.; Akkucuk, U. The relationship between renewable energy use and health expenditures in EU countries. Eur. J. Health Econ. 2021, 22, 1129-1139. [CrossRef]

8. Tokol, A. Çokuluslu Şirketler ve Endüstri İlişkilerine Etkileri. Endüstri İlişkileri ve İnsan Kaynakları Dergisi $2001,3,2$.

9. Yavuz, C.; Sivrikaya, D. Küreselleşmenin aktörlerinden çokuluslu şirketler ve yönetişim. In Proceedings of the Küresel Diyalog Konferansı Uluslararası Davraz Kongresi, Isparta, Turkey, 24-27 September 2009; pp. 1217-1236. 
10. Işık, H. Çok Uluslu Şirketlerde Örtülü Kazanç ve Örtülü Sermaye; TC Maliye Bakanlığı Araştırma, Planlama ve Koordinasyon Kurulu Başkanlığı, Yayın: Ankara, Turkey, 2005; pp. 2005-2370.

11. Yahşi, F. Küreselleşme ve İstihdam. Master's Thesis, Çukurova University, Adana, Turkey, 2007.

12. Gilson, L.L.; Maynard, M.T.; Jones Young, N.C.; Vartiainen, M.; Hakonen, M. Virtual teams research: 10 years, 10 themes, and 10 opportunities. J. Manag. 2015, 41, 1313-1337. [CrossRef]

13. Soydemir, S.; Özdaşlı, K.; Alparslan, A.M. Görev-İnsan Odaklı Liderlik Algılamasının Vatandaşa Yönelik Prososyal Hizmet Davranışlarına Etkisi: Kolluk Kuvvetleri Üzerine Bir Araştırma. Afyon Kocatepe Üniversitesi İktisadi ve İdari Bilimler Fakültesi Dergisi 2014, 16, 63-81.

14. Aydın, M. Eğitim Yönetimi; Hatipoğlu Yayınları: Ankara, Turkey, 1994.

15. Bulut, H.; Meydan, C.H. Liderlik Tarzlarının Çalışanların Ses Verme Davranışına Etkisi: Kamuda Bir Araştırma. Ankara Üniversitesi SBF Dergisi 2018, 73, 223-244.

16. Fey, C.F.; Adaeva, M.; Vitkovskaia, A. Developing a Model of Leadership Styles: What Works Best in Russia? Int. Bus. Rev. 2001, 10, 615-643. [CrossRef]

17. Özkılıçcı, G.; Mamatoğlu, N. Yeni Koronavirüs (COVID-19) Salgını: Tutumlar, Algılar ve Siyasi Lider Stili Tercihi. Altern. Politics/Altern. Polit. 2021, 13, 208-246.

18. Hill, N.S.; Bartol, K.M. Empowering Leadership And Effective Collaboration İn Geographically Dispersed Teams. Pers. Psychol. J. 2016, 69, 159-198. [CrossRef]

19. Wakefield, R.L.; Leidner, D.E.; Garrison, G. Research Note-A Model of Conflict, Leadership and Performance in Virtual Teams. Inf. Syst. Res. 2008, 19, 434-455. [CrossRef]

20. Boulding, K. Conflict and Defense; Harper \& Row: New York, NY, USA, 1962.

21. Jehn, K.A. A Multimethod Examination of The Benefits And Detriments of Intragroup Conflict. Adm. Sci. Q. 1995, 40, 256-282. [CrossRef]

22. Griffith, T.L.; Sawyer, J.E.; Neale, M.A. Virtualness And Knowledge in Teams: Managing The Love Triangle of Organizations, Individuals, and Information Technology. MIS Q. 2003, 27, 265-287. [CrossRef]

23. Jehn, K.; Mannix, E. The Dynamic Nature of Confllict: A Longitudinal Study of Intragroup Conflict And Group Performance. Acad. Manag. J. 2001, 44, 238-251.

24. Cramton, C.D. The Mutual Knowledge Problem and Its Consequences for Dispersed Collaboration. Organ. Sci. 2001, 12, 346-371. [CrossRef]

25. Marks, M.A.; Mathieu, J.E.; Zaccaro, S. A Temporally Based Framework and Taxonomy of Team Processes. Acad. Manag. Rev. 2001, 26, 356-376. [CrossRef]

26. Carte, T.A.; Chidambaram, L.; Becker, A. Emergent Leadership in Self-Managed Virtual Teams. Group Decis. Negot. 2006, 15, 323-343. [CrossRef]

27. Hoch, J.E.; Kozlowski, S.W. Leading Virtual Teams: Hierarchical Leadership, Structural Support and Shared Team Leadership. J. Appl. Psychol. 2014, 99, 390-403. [CrossRef]

28. Al-Ani, B.; Horspool, A.; Bligh, M.C. Collaborating with 'Virtual Strangers': Towards Developing a Framework For Leadership in Distributed Teams. Leadership 2011, 7, 219-249. [CrossRef]

29. Brake, T. Leading Global Virtual Teams. Ind. Commer. Train. 2006, 38, 116-121. [CrossRef]

30. Avolio, B.J.; Sosik, J.J.; Kahai, S.; Baker, B. E-Leadership: Re-Examining Transformations in Leadership Source And Transmission. Leadersh. Q. 2014, 25, 105-131. [CrossRef]

31. Zaccaro, S.J.; Bader, P. E-leadership and the challenges of leading e-teams: Minimizing the bad and maximizing the good. Organ Dyn. 2003, 31, 377-387. [CrossRef]

32. School, H.B. Sanal Ekiplere Liderlik Etmek; Optimist Yayıncılık: İstanbul, Turkey, 2011.

33. Handke, L.; Klonek, F.E.; Parker, S.K.; Kauffeld, S. Interactive Effects of Team Virtuality and Work Design on Team Functioning. Small Group Res. 2020, 51, 3-47. [CrossRef]

34. Malhotra, A.; Majchrzak, A.; Rosen, B. Leading Virtual Teams. Acad. Manag. Perspect. 2007, 21, 60-70. [CrossRef]

35. Okay, A.; Okay, A. Halkla İlişkiler: Kavram, Strateji ve Uygulamaları; Der Yayınları: İstanbul, Turkey, 2002.

36. Jarvenpaa, S.L.; Leidner, D.E. Communication And Trust in Global Virtual Teams. J. Comput.-Mediat. Commun. 1999, 10, 791-815. [CrossRef]

37. Yücebalkan, B. Postmodern Yönelimli Sanal Organizasyonlarda Liderlik Konsepti. Doctoral Thesis, Kocaeli University, Kocaeli, Turkey, 2003.

38. Naktiyok, A. E-Liderlik: E-Liderlik Özelliklerinin İncelenmesine Yönelik Bir Araştırma. Dokuz Eylül Üniversitesi İşletme Fakültesi Dergisi 2006, 7, 19-40.

39. Maduka, N.S.; Edwards, H.; Greenwood, D.; Osborne, A.; Babatunde, S.O. Analysis of competencies for effective virtual team leadership in building successful organisations. Benchmark. Int. J. 2018, 25, 696-712. [CrossRef]

40. Çırpan, H.; Yomralığlu, D. Essential Leadership Qualities for High Performing Virtual Teams. Ekonomi İşetme ve Maliye Araştırmaları Dergisi 2020, 2, 265-279. [CrossRef]

41. Hennink, M.M. Understanding Focus Group Discussions; Oxford University Press: Oxford, UK, 2014.

42. Morgan, D.L. Focus Groups. Annu. Rev. Sociol. 1996, 22, 129-152. [CrossRef]

43. Krueger, R.A. Focus Groups: A Practical Guide For Applied Research, 2nd ed.; Sage Publications: Thousand Oaks, CA, USA, 1994. 
44. Hennink, M.; Hutter, I.; Bailey, A. Qualitative Research Methods; Sage Publications Ltd.: London, UK, 2011.

45. Gençer, Y.G. Measuring Value along The Supply Chain: A Study on White Goods Sector. Elektron. Sos. Bilimler Derg. 2018, 17, 688-703.

46. Hinkin, T.R. A Review of Scale Development Practices in The Study of Organizations. J. Manag. 1995, 21, 967-988. [CrossRef]

47. Kapuscinski, A.N.; Masters, K.S. The Current Status of Measures of Spirituality: A Critical Review of Scale Development. Psychol. Relig. Spiritual. 2010, 2, 191-205. [CrossRef]

48. Arias, M.R.M.; Lloreda, M.J.H.; Lloreda, M.V.H. Psicometria; SA Alianza Editorial: Madrid, Spain, 2006

49. Devellis, R.F. Scale Development: Theory And Applications; Sage Publications: Thousand Oaks, CA, USA, 2016 ; Volume 26.

50. Krueger, R.A. Focus Groups: A Practical Guide For Applied Research, 5th ed.; Sage Publications: Thousand Oaks, CA, USA, 2014.

51. Gencer, Y.G.; Akkucuk, U. Measuring quality in automobile aftersales: AutoSERVQUAL Scale. Amfiteatru Econ. 2017, 19, 110-123.

52. De Vaus, D.A. Research Design in Social Research; Sage: London, UK, 2001.

53. Altunışık, R. Anketlerde Veri Kalitesinin İyileştirilmesi İçin Öntest (Pilot Test) Yöntemleri. Pazarlama ve Pazarlama Araştırmaları Dergisi 2008, 2, 1-17.

54. Hair, J.F., Jr.; Black, W.C.; Babin, B.J.; Anderson, R.E.; Tatham, R.L. Multivariate Data Analysis, 6th ed.; Pearson Prentice Hall: Hoboken, NJ, USA, 2005.

55. Karaszewski, R.; Drewniak, R. The Leading Traits of the Modern Corporate Leader: Comparing Survey Results from 2008 and 2018. Energies 2021, 14, 7926. [CrossRef]

56. Yahaya, R.; Ebrahim, F. Leadership styles and organizational commitment: Literature review. J. Manag. Dev. 2016, 35, 190-216. [CrossRef]

57. Drewniak, R.; Drewniak, Z.; Posadzinska, I. Leadership Syles and Employee Expectations. Eur. Res. Stud. J. 2020, $23,398-411$. [CrossRef]

58. Oc, B. Contextual leadership: A systematic review of how contextual factors shape leadership and its outcomes. Leadersh. Q. 2018, 29, 218-235. [CrossRef]

59. Akkucuk, U. (Ed.) Handbook of Research on Developing Sustainable Value in Economics, Finance, and Marketing; IGI Global: Hershey, PA, USA, 2015. [CrossRef] 